\title{
Kinetics of Nitrite Oxidation by Nitrobacter winogradskyi
}

\author{
By B. BOON AND H. LAUDELOUT \\ Institut Agronomique, University of Louvain, Louvain, Belgium
}

(Received 12 April 1962)

Preliminary data on the kinetics of the oxidation of nitrite by Nitrobacter were presented by Laudelout \& van Tichelen (1960). The present observations complete and extend the results concerning the effects of $\mathrm{pH}$, concentrations of nitrite and of nitrate, temperature and oxygen partial pressure on the parameters of the rate equation for the oxidation of nitrite by intact cells and cell-free extracts.

Results on some of these aspects of the physiology of Nitrobacter may be found in the literature; that they are not more abundant is largely due to problems connected with the growth of this organism in the Laboratory. Until recently (Goldberg \& Gainey 1955) it was thought that suspended mineral matter was absolutely necessary for the normal growth of Nitrobacter. Harvesting of the cells from media containing calcium carbonate and phosphate gave mineral slurries in which, in view of the sorptive properties of the precipitates, uncertainties resulted during the study of the relationship between the rate of oxidation and the concentrations of ions. This is not, however, the main reason for ascertaining the kinetics of the oxidation rate of nitrite by Nitrobacter cells and cell-free extracts. The determination of the parameters of the rate equations should lead to a better understanding of the mechanism of the process. If the rate constants for intact cells and cell-free extracts are identical or nearly so, this would mean that the nitrite-oxidizing system may be localized at the cell surface or that permeability effects are entirely negligible, the latter being unlikely for a charged substrate and reaction product.

\section{MATERIALS AND METHODS}

The cells were grown according to a continuous dialysis procedure which allows the removal of the reaction product, nitrate, which is inhibitory for the growth process at fairly low concentration. Fresh sterile medium was circulated through dialysis tubing immersed in a 21 . cylindrical vessel, aerated through a sintered-glass bottom plate. The incubation temperature was $30^{\circ}$, which gives optimum growth of the strain used. The composition of the culture medium was (per l. of water): $\mathrm{NaNO}_{2}, 2 \cdot 38 \mathrm{~g}$.; $\mathrm{Na}_{2} \mathrm{HPO}_{4}$, $2 \mathrm{H}_{2} \mathrm{O}, 3 \cdot 2$ g.; $\mathrm{KH}_{2} \mathrm{PO}_{4}, 0 \cdot 272$ g.; $\mathrm{FeSO}_{4}, 7 \mathrm{H}_{2} \mathrm{O}, 1 \mathrm{mg}$.; $\mathrm{MgSO}_{4}, 7 \mathrm{H}_{2} \mathrm{O}, 10 \mathrm{mg}$. The $\mathrm{pH}$ of this solution was $7 \cdot 6$ and was not further adjusted. The cells were harvested by centrifuging at $12500 \mathrm{~g}$ for $5 \mathrm{~min}$. They were washed with
20 mM-phosphate buffer, pH 7.65 (18 mM-Na $\mathrm{HPO}_{4}$ plus $\left.2 \mathrm{mM}_{-} \mathrm{KH}_{2} \mathrm{PO}_{4}\right)$.

All respiration measurements were made with the usual Warburg technique with $2.5 \mathrm{ml}$. of the cell suspension in the flask to which $0.5 \mathrm{ml}$. of the substrate and inhibitors was added from the side arm to give the final concentration required. No KOH was used in the centre well, the endogenous respiration being negligible for Nitrobacter cells.

Cell-free extracts were obtained by ultrasonic treatment for $45 \mathrm{~min}$. of $20 \mathrm{ml}$. of a washed cell suspension containing 200-300 mg. dry wt. at 9 kcyc./sec. in a Raytheon model S102 A apparatus under a nitrogen atmosphere. Centrifuging at $10000 \mathrm{~g}$ for $15 \mathrm{~min}$. separated a supernatant which had a measurable respiratory activity.

The possibility of obtaining active Nitrobacter extracts was first demonstrated for Nitrobacter agilis by Aleem \& Alexander (1958) and for Nitrobacter winogradskyi by Lees (1958). Nitrite determinations were made according to Shin's (1941) method involving the diazotization of sulphanilamide followed by coupling with $N$-1-naphthylethylenediamine dihydrochloride.

\section{RESULTS}

Effect of nitrite concentration on the oxidation rate. When the effect of a wide range of nitrite concentrations on the rate of oxygen uptake by intact cells or cell-free extracts is observed, a typical substrate-inhibition curve results (Fig. 1). Meyerhof (1916) noted that, at concentrations above $20 \mathrm{~mm}$, nitrite inhibits the rate of its own oxidation. According to Lees \& Simpson (1957) inhibitory effects would already be noticeable at concentrations as low as $4 \mathrm{~mm}$. An explanation of the inhibitory effect of nitrite on its own oxidation has been presented by Butt \& Lees (1960), correlating the rate of transport of nitrite and oxygen into the cell. Although there may be interactions between partial oxygen pressure and the oxidation of nitrite in Nitrobacter, the actual mechanism of nitrite toxicity has been found to be more simple.

Interpretation of the data of Fig. 1 is feasible according to the usual method for calculating substrate inhibition, which yields an equation of the type:

$$
v=\frac{V[\mathrm{~S}]}{\left(K_{m}+[\mathrm{S}]\right)\left(1+\frac{[\mathrm{S}]}{K_{t}}\right)}
$$

where $V$ is the theoretical maximum rate should there be no substrate inhibition, [S] the substrate 
concentration, and $K_{m}$ and $K_{t}$ two constants representing the dissociation constants of the active and inactive enzyme-substrate complexes respectively. For intact cells, the values of $K_{m}$ and $K_{t}$ which ensure the best fit of the theoretical curve to the experimental points are $1.6 \mathrm{~mm}$ and $130 \mathrm{~mm}$ respectively.

Differentiating eqn. (1) with respect to [S] shows that the nitrite concentration at which the rate of oxidation is maximum, $[\mathrm{S}]_{\max }$, is $14.5 \mathrm{~mm}$. The rate at this concentration is $81.5 \%$ of the theoretical maximum rate, $V$.

$V$ is calculated by equating, in eqn. (1), $v$ to 100 arbitrary units for a substrate concentration, [S], of $14.5 \mathrm{~mm}$. The corresponding value of $V$ is then 123 , or $148 \mu \mathrm{l}$. of $\mathrm{O}_{2} / \mathrm{hr} . / \mathrm{ml}$. of suspension for the experimental conditions of Fig. 1, as against the $120 \mu \mathrm{l}$. of $\mathrm{O}_{2} / \mathrm{hr}$. $/ \mathrm{ml}$. found at the optimum substrate concentration.

Eqn. (1) is represented by the full line of Fig. 1. The agreement with the experimental points is satisfactory, but this proves little since three constants must be manipulated to ensure the fit of the theoretical curve to the experimental data. The broken line in Fig. 1 represents the theoretical Michaelis-Menten curve that would be obtained in the absence of substrate inhibition.

The fit of the experimental data to the theoretical curve is not as arbitrary as it may at first seem, since the values of $K_{m}$ and $K_{t}$ can be checked

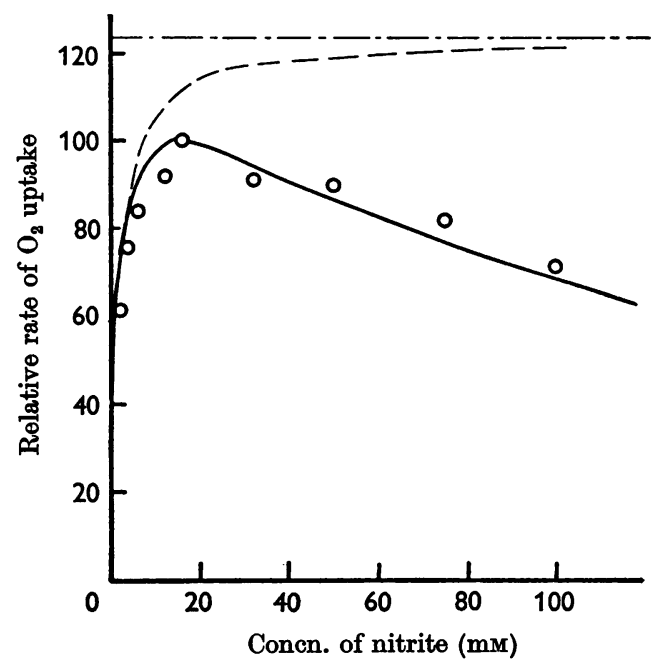

Fig. 1. Relative rate of oxidation of nitrite by intact Nitrobacter winogradskyi cells at various nitrite concentrations at $32^{\circ}$ and $\mathrm{pH} 7 \cdot 6$. Full line: theoretical curve according to eqn. (1); broken line: theoretical rate of nitrite oxidation in the absence of substrate inhibition. A relative rate of 100 corresponds to an oxygen uptake of $120 \mu \mathrm{l}$. of $\mathrm{O}_{2} / \mathrm{hr}$. $/ \mathrm{ml}$. of suspension. independently of one another: $K_{m}$ can be found as the slope of a graph of $v$ against $v /[\mathrm{S}]$ for substrate concentrations lower than $10 \mathrm{mM}$, and $K_{t}$ can be measured from a graph giving the variations of $V / v$ for substrate concentrations higher than 20 mM. Nevertheless, not much significance can be attached to the meaning of the constant $K_{t}$. This is a consequence of the purely formal derivation of eqn. (1) for substrate inhibition. A further disadvantage of this derivation is that it takes no account of the well-known inhibition of the cells' metabolism by the weakly dissociated nitrous acid originating from the hydrolysis of the substrate. This has been shown by Eddy (1958) in his work on nitratase and more recently by Silver (1960) in a study on Nitrobacter sp.

If, as shown below, inhibition by nitrous acid is non-competitive, we should obtain a relation between the rate of oxidation of nitrite and the concentration of nitrous acid such as:

$$
v=\frac{V[\mathrm{~S}]}{\left(K_{m}+[\mathrm{S}]\right)\left(1+\frac{\left[\mathrm{HNO}_{2}\right]}{K_{i}}\right)}
$$

where $K_{i}$ is the dissociation constant of the enzyme-nitrous acid complex.

Since the concentrations of substrate and nitrous acid are related to one another by the equilibrium relation of the acid-base dissociation of the latter:

$$
K_{\mathrm{HNO}_{2}}=\frac{\left[\mathrm{H}^{+}\right]\left[\mathrm{NO}_{2}^{-}\right]}{\left[\mathrm{HNO}_{2}\right]}=10^{-3 \cdot 4}
$$

and since:

$$
[\mathrm{S}]=\left[\mathrm{NO}_{2}^{-}\right]+\left[\mathrm{HNO}_{2}\right] \cong\left[\mathrm{NO}_{2}^{-}\right]
$$

eqn. (2) may be expressed as:

$$
v=\frac{V[\mathrm{~S}]}{\left(K_{m}+[\mathrm{S}]\right)\left(1+\frac{[\mathrm{S}]\left[\mathrm{H}^{+}\right]}{K_{\mathrm{HNO}_{2}} K_{i}}\right)}
$$

Eqn. (3) is formally identical with eqn. (1), and the value found above for $K_{t}$ may be used for calculating $K_{i}$, the inhibition constant of nitrous acid. We then obtain:

$$
K_{i}=\frac{K_{t}\left[\mathrm{H}^{+}\right]}{K_{\mathrm{HNO}_{2}}}=\frac{130 \times 10^{-7 \cdot 6}}{10^{-3 \cdot 4}}=8 \cdot 2 \mu \mathrm{M}
$$

According to this theory $K_{t}$ should be $\mathrm{pH}$ dependent, and a study of the $\mathrm{pH}$-dependence of the oxidation rate at various nitrite concentrations could confirm this mechanism. To do so we measured the effect of the calculated nitrous acid concentration at various $\mathrm{pH}$ values and nitrite concentrations. When the rate is plotted against the nitrous acid concentration as calculated from its acid-base equilibrium equation, all points should fall on a single curve. Fig. 2 shows that this is so. 
The inhibition constant, $K_{i}$, may be calculated by plotting the uninhibited rate, $v_{0}$, against the inhibited rate, $v$, at the corresponding nitrous acid concentration. Since there is some nitrous acid present at all concentrations and $\mathrm{pH}$ values, we have used for $v_{0}$ the theoretical maximum rate, $V$, calculated from eqn. (1). The reciprocal of the slope of this graph gives $K_{i}$, which is found to be 13.5 $\mu \mathrm{M}$. This value is close to that calculated above from the $K_{t}$ value, i.e. $8 \cdot 2 \mu \mathrm{M}$.

The $K_{i}$ found for cell-free extracts was $8 \mu \mathrm{M}$. The similarity between this value and the one found for intact cells shows that it is unlikely that permeability effects could be effective in nitrite inhibition.

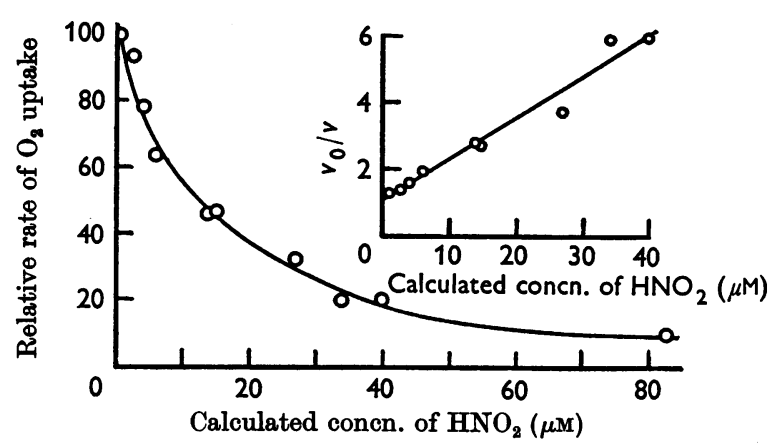

Fig. 2. Relative rate of oxidation of nitrite by intact Nitrobacter winogradskyi cells at various $\mathrm{pH}$ values and nitrite concentrations plotted against the calculated concentration of nitrous acid. A relative rate of 100 corresponds to an oxygen uptake of $180 \mu \mathrm{l}$. of $\mathrm{O}_{2} / \mathrm{hr} . / \mathrm{ml}$. of suspension. The insert shows a plot of the ratio of the uninhibited rate to the inhibited rate at the corresponding concentration of nitrous acid.

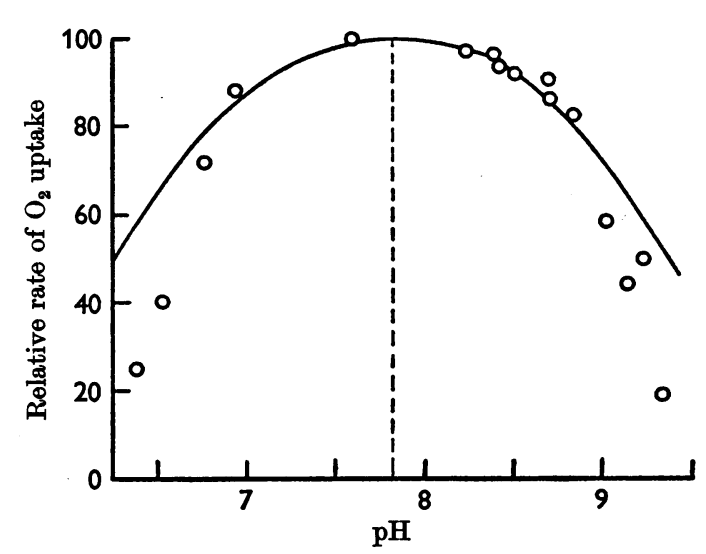

Fig. 3. Relative rate of the oxidation of nitrite by intact Nitrobacter winogradskyi cells at $32^{\circ}$ plotted against $\mathrm{pH}$. The substrate concentration was $16 \mathrm{~mm}$. Full line: theoretical curve as explained in the text. A relative rate of 100 (i.e. at optimum $\mathrm{pH}$ ) corresponds to an oxygen uptake of $290 \mu \mathrm{l}$. of $\mathrm{O}_{2} / \mathrm{hr}$./ml. of suspension.
Effect of $\mathrm{pH}$ on the oxidation rate. The oxygen uptake by Nitrobacter cell suspensions or cell-free extracts was observed in the $\mathrm{pH}$ range 6.4-9.4. The buffer concentration (phosphate, tris, bicarbonate or glycine, according to the $\mathrm{pH}$ range) was always 20 mM. Their cationic compositions were as follows: phosphate, disodium hydrogen phosphate and potassium dihydrogen phosphate; tris, $0.02 \mathrm{M}$ tris adjusted with $2 \mathrm{~N}$-hydrochloric acid; bicarbonate, dipotassium carbonate and sodium hydrogen carbonate; glycine, 0.02 M-glycine adjusted with $2 \mathrm{~N}$-sodium hydroxide. At a nitrite concentration of $16 \mathrm{~mm}$ the curve given in Fig. 3 is observed for intact cells.

The results from the inhibition by nitrous acid allow us to calculate immediately the acid portion of the $\mathrm{pH}$-activity curve. We may consider this curve as representing inhibition by nitrous acid, the concentration of which increases when the $\mathrm{pH}$ decreases and may be calculated from the $\mathrm{H}^{+}$ion concentration and the dissociation constant of nitrous acid. If the acid portion of the $\mathrm{pH}$-activity curve is calculated in this way, the agreement between the theoretical curve and the experimental points shows that this is the likeliest explanation for the decrease of the oxidation rate with the $\mathrm{pH}$.

To explain the alkaline branch of the curve, we may proceed in a more usual fashion: if we admit a competitive inhibition of the adsorption of nitrite on the enzyme sites by $\mathrm{OH}^{-}$ions, the rate should become

$$
v=\frac{V[\mathrm{~S}]}{K_{m}\left(1+\frac{\left[\mathrm{OH}^{-}\right]}{K_{i}^{\prime}}\right)+[\mathrm{S}]}
$$

where $K_{\text {; }}^{\prime}$ is the dissociation constant of the enzyme- $\mathrm{OH}^{-}$ion complex. Fig. 4 shows that the inhibition by $\mathrm{OH}^{-}$ions is indeed competitive, since plotting the rate observed at various $\mathrm{pH}$ values for various nitrite concentrations in a double reciprocal plot gives straight lines with a common intercept on the $1 / v$ axis. $K_{i}^{\prime}$ of eqn. (4) may thus be calculated and is found to be $10^{-5 \cdot 6} \mathrm{M}$, i.e. $2.5 \mu \mathrm{M}$.

Eqn. (4) may be transformed in terms of $\mathrm{H}^{+}$ion concentrations to give:

$$
v=\frac{V[\mathrm{~S}]}{K_{m}\left(1+\frac{K_{b}}{\left[\mathrm{H}^{+}\right]}\right)+[\mathrm{S}]}
$$

where $K_{b}$ is now the basic acid-base dissociation constant of the active enzyme site, which is thus:

$$
K_{b}=\frac{K_{i}^{\prime}}{K_{w}}=10^{-8 \cdot 4}
$$

$K_{w}$ being the ionic constant product of water. 
Eqn. (5) is represented by the curve on the alkaline side of the $\mathrm{pH}$-activity curve and the agreement with the experimental values is good.

Below $\mathrm{pH} 6.5$ or above $\mathrm{pH} 9.0$ there is disagreement between the theoretical curve and the experimental points. We could improve the agreement below $\mathrm{pH} 6.5$ by taking into account the first dissociation constant of the active site, which has been entirely neglected. This would increase the slope of the acid branch of the theoretical curve and provide a better fit. Although this is theoretically feasible, it would not be very reasonable to submit the few experimental points which have been obtained for the range below $\mathrm{pH} \mathrm{6.5}$ to such involved calculation. There is always the possibility that, during the thermal equilibration, some irreversible denaturation of the enzymic system occurs when the $\mathrm{pH}$ of the cell suspension is either very low or very high (above $\mathrm{pH} 9 \cdot 0$ ).

With this reservation the general rate equation for $\mathrm{pH}$ effects may be formulated as in eqn. (6):

$$
v=\frac{V[\mathrm{~S}]}{\left\{K_{m}\left(1+\frac{K_{b}}{\left[\mathrm{H}^{+}\right]}\right)+[\mathrm{S}]\right\}\left(1+\frac{[\mathrm{S}]\left[\mathrm{H}^{+}\right]}{K_{i} K_{\mathrm{HNO}_{2}}}\right)}
$$

$V$ in eqn. (6) may be easily calculated and is $1 \cdot 165$ times the observed value of $v$ at $\mathrm{pH} 7.82$ with a nitrite concentration of $16 \mathrm{~mm}$.

By equating to zero the derivative of $v$ with respect to the $\mathrm{H}^{+}$ion concentration the optimum $\mathrm{pH}$ is found to be $\mathbf{7 \cdot 8 2}$.

Effect of $\mathrm{pH}$ on $K_{m}$. The determination of the $K_{m}$ of cell-free extracts or intact cells at $32^{\circ}$ and $\mathrm{pH} 7.65$ gives values of 3.58 and $1.6 \mathrm{~mm}$ respectively. This is significantly different from the value which has been reported previously for intact cells obtained from the classical culture solution with suspended mineral precipitate and which were oxidizing nitrite in the Warburg flasks in the presence of a high concentration of particulate

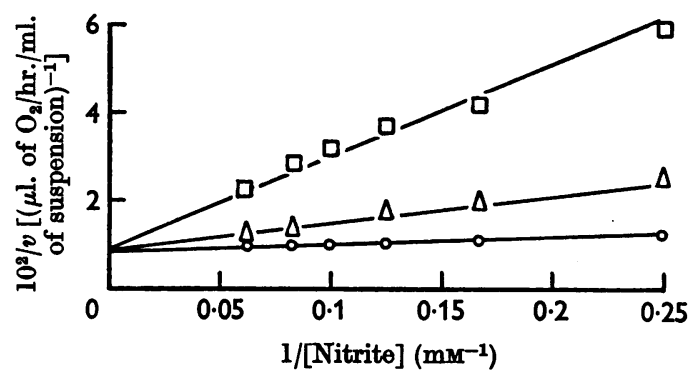

Fig. 4. Double reciprocal plot of the rate of oxidation of nitrite by intact Nitrobacter winogradskyi cells at $32^{\circ}$ at various $\mathrm{pH}$ values with various nitrite concentrations. O, pH 7.7; $\triangle$, pH 8.85; $\square, \mathrm{pH} 9 \cdot 15$. matter (Laudelout \& van Tichelen, 1960). Since this precipitate has sorptive properties there is a possibility that the concentration relationships for the cells are different. This may be related to an observation by Hattori \& Furusaka (1960), who found that optimum $\mathrm{pH}$ values of cells adsorbed on an ion-exchange resin were higher by $1 \mathrm{pH}$ unit. Neglecting for the moment the discrepancy between the values quoted above for intact cells and cellfree extracts, we may examine the $\mathrm{pH}$ relationships of the $K_{m}$ parameter.

It is easily seen from eqn. (5) that $K_{m}$ must be pH-dependent, the relationship being :

$$
K_{m}=K_{m}^{0}\left(1+\frac{K_{b}}{\left[\mathrm{H}^{+}\right]}\right)
$$

where $K_{m}^{0}$ represents the constant value of $K_{m}$ at a $\mathrm{pH}$ which is much lower than $\mathrm{p} K_{b}$. The value of $K_{m}^{0}$, the $\mathrm{pH}$-independent Michaelis constant, is $1.6 \mathrm{~mm}$ for intact cells. For $\mathrm{pH}$ values greater than $\mathrm{p} K_{b}, \mathrm{p} K_{m}$ should vary linearly with $\mathrm{pH}$, the slope of the line being unity. Fig. 5 shows that this is actually the case. As shown by Dixon \& Webb (1958), the distance between the rounded part of the curve and the intersection of the two straight lines: $\mathrm{p} K_{m}=\mathrm{p} K_{m}^{0}$, and $\mathrm{p} K_{m}=\mathrm{p} K_{m}^{0}+\mathrm{p} K_{b}-\mathrm{pH}$, should be $0.3 \mathrm{pH}$ unit. The abscissa of this intersection should have the value $\mathrm{pH}=\mathrm{p} K_{b}$, which gives a new determination of $\mathrm{p} K_{b}$. We find here that $\mathrm{p} K_{b}$ is $\mathbf{8 \cdot 3}$, which is identical with the value found from the $\mathrm{pH}$-activity curve.

$\mathrm{pH}$-activity curve of the cell-free extract. The influence of $\mathrm{pH}$ on the oxidation rate of a cell-free extract is somewhat different from that on intact cells (Fig. 6). The pH range in which the rate of oxidation of nitrite exceeds $50 \%$ of the optimum is much more narrow. We find that this narrowing is due to a displacement of the alkaline branch of the curve towards lower $\mathrm{pH}$ values. This displacement

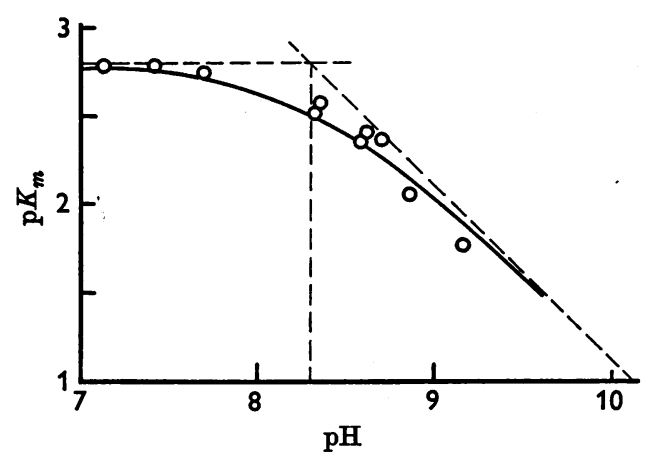

Fig. 5. Negative logarithm of the Michaelis constant, $K_{m}$, plotted as a function of $\mathrm{pH}$, for the oxidation of nitrite by intact Nitrobacter winogradskyi cells at $32^{\circ}$. Full line: theoretical curve as explained in the text. 
may be characterized by a shift of $\mathrm{p} K_{b}$ from 8.3 to 7.8. There is no significant difference in $K_{i}$, which is found to be again $8 \mu \mathrm{M}$ for cell-free extracts.

From the general eqn. (6) for pH effects one may calculate the optimum $\mathrm{pH}$ for cell-free extracts as $\mathrm{pH} 7 \cdot 71$, the theoretical maximum rate, $V$, being 137.5 in arbitrary units if the rate with $16 \mathrm{~mm}$ nitrite at $\mathrm{pH} 7 \cdot 71$ and $32^{\circ}$ is set equal to 100 . The theoretical curve for these values of parameters has been drawn as a full line on Fig. 6.

The $K_{m}$ for cell-free extracts is not very different from that for intact cells if $\mathrm{pH}$ effects are taken into account: the $K_{m}^{0}$ values for cell-free extracts and intact cells are 2.2 and $1.6 \mathrm{mM}$ respectively. This difference is certainly within the order of

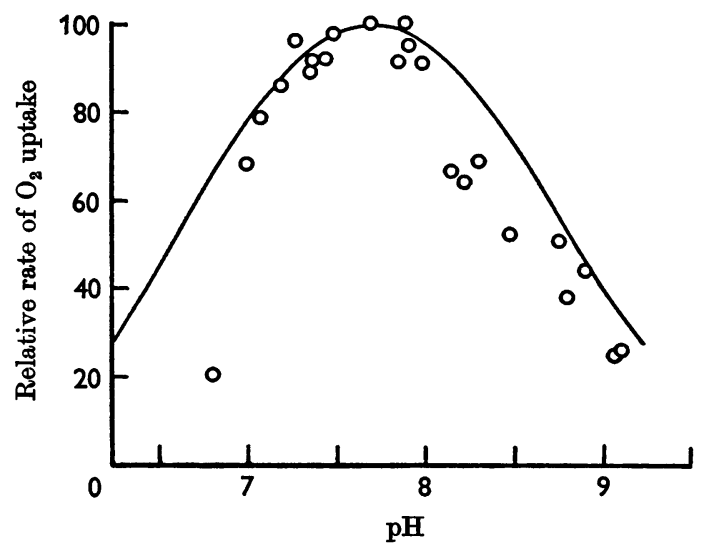

Fig. 6. Relative rate of oxidation of nitrite by cell-free extracts of Nitrobacter winogradskyi at $32^{\circ}$ plotted as a function of $\mathrm{pH}$. The substrate concentration was $16 \mathrm{~mm}$. Full line: theoretical curve explained in text. A relative rate of 100 (i.e. at optimum $\mathrm{pH}$ ) corresponds to an oxygen uptake of $250 \mu \mathrm{l}$. of $\mathrm{O}_{2} / \mathrm{hr}$./ml. of suspension.

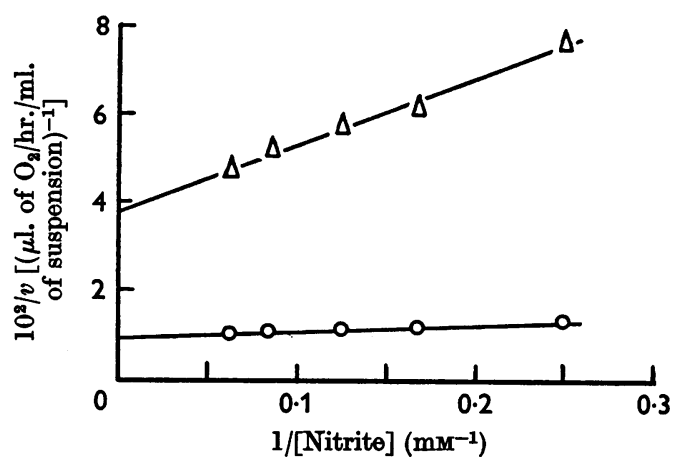

Fig. 7. Double reciprocal plot of the rate of oxidation of nitrite by intact Nitrobacter winogradskyi cells at $32^{\circ}$ and pH 7.6 at various nitrite concentrations in the presence of nitrate at concentrations of $25 \mathrm{mM}(O)$ and $200 \mathrm{~mm}(\triangle)$. magnitude of the experimental error for the calculated $K_{m}^{0}$ values.

Effect of nitrate on the oxidation of nitrite. Several authors have already studied the influence of nitrate on the rate of oxidation of nitrite; most of them reported an initial stimulation of the rate up to a concentration of about $0 \cdot 1 \mathrm{M}$ (Meyerhof, 1916; Zavarzin, 1958). Butt \& Lees (1960) mention that nitrate at a concentration of $33 \mathrm{~mm}$ inhibits the oxidation of nitrite at high oxygen concentrations, but stimulates it at lower oxygen concentrations. While working with Nitrobacter growing on a culture medium containing precipitated salts we have also observed an initial stimulation of the oxidation of nitrite. This may be due to the fact that trace elements essential for the respiration and which have been strongly adsorbed on the mineral particles are released by an ion-exchange process when nitrate is added to the washed suspension of cells and mineral precipitate. If, however, Nitrobacter cells are grown on a medium free from a solid phase, the possibility of which was first demonstrated by Goldberg \& Gainey (1955), there is no such initial stimulation of the oxidation of nitrite. As shown in Fig. 7 we find a simple noncompetitive inhibition.

The slope of the plot of $v_{0} / v$ against the nitrate concentration allows the calculation of the inhibition constant of nitrate in the expression of the non-competitive inhibition. The equation

$$
v=\frac{V[\mathrm{~S}]}{\left(K_{m}+[\mathrm{S}]\right)\left(1+\frac{\left[\mathrm{NO}_{3}^{-}\right]}{K_{i}^{\prime \prime}}\right)}
$$

with a dissociation constant of the enzyme$\mathrm{NO}_{3}^{-}$ion complex, $K_{i}^{\prime \prime}$, of $180 \mathrm{mM}$, is represented by the curve of Fig. 8 .

The constants which determine the rate of the oxidation of nitrite, as a function of the $\mathrm{pH}$, substrate concentration and reaction-product concentration, by intact cells and cell-free extracts are summarized in Table 1.

Effect of oxygen partial pressure on the rate of oxidation of nitrite. The influence of the partial pressure of oxygen was measured by evacuating and filling at atmospheric pressure the Warburg flasks with mixtures of oxygen and nitrogen where the partial pressure of oxygen ranged from 2.6 to $21 \%$. All measurements were carried out on cell suspensions with $16 \mathrm{~mm}$-nitrite at $\mathrm{pH} 7 \cdot 6$. They were carried out at five temperatures: $20^{\circ}, 23 \cdot 7^{\circ}$, $29^{\circ}, 32^{\circ}$ and $35^{\circ}$. The amounts of oxygen dissolved at each partial pressure and each temperature were calculated from gas-solubility tables. The results are given in Table 2.

If the rate, $v$, is plotted against $v /[\mathrm{S}]$, i.e. the rate divided by oxygen concentration, this will give the 
$K_{m}$ (oxygen) of the terminal oxidase of the respiratory chain with respect to the substrate oxygen. When the logarithm of this value is plotted against the reciprocal of the absolute temperature, a straight line is obtained (Fig. 9). Since the individual determinations of $K_{m}$ (oxygen) are not very precise, the value of $K_{m}$ (oxygen) at $32^{\circ}$ has been interpolated in Fig. 9. This gives a value of $K_{m}$ (oxygen) of $16 \mu \mathrm{M}$ or a partial pressure of $1.5 \%$.

The slope of the straight line of Fig. 9 gives an enthalpy variation of $12.5 \mathrm{kcal}$. compared with $19.5 \mathrm{kcal}$. for the $\Delta H$ calculated from the variation of $K_{m}$ (nitrite) with the temperature (Laudelout \& van Tichelen, 1960). If the decrease of the oxygen concentration is followed with a platinum microelectrode in cell suspensions containing nitrite and the equilibrium amount of dissolved oxygen, the time-course of the reaction will be given by the integrated Michaelis-Menten equation

$$
\ln \left(\frac{[\mathrm{S}]_{0}}{[\mathrm{~S}]_{0}-[\mathrm{S}]}\right)=\frac{V t}{\left.K_{m} \text { (oxygen }\right)}-\frac{[\mathrm{S}]}{K_{m}(\text { oxygen })}
$$

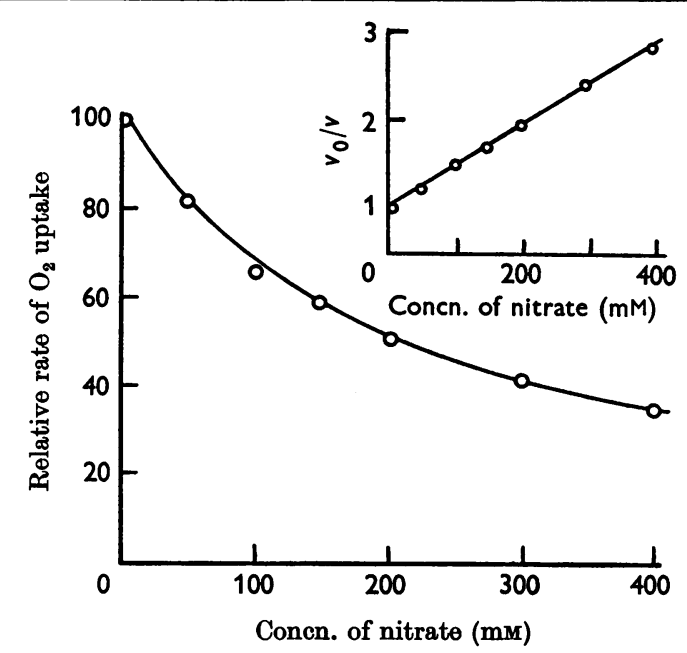

Fig. 8. Effect of nitrate on the relative rate of oxidation of nitrite by intact Nitrobacter winogradskyi cells at $32^{\circ}$ and pH 7.6. The substrate concentration was $16 \mathrm{~mm}$. Full line: theoretical curve as explained in the text. A relative rate of 100 corresponds to an oxygen uptake of $120 \mu \mathrm{l}$. of $\mathrm{O}_{2} / \mathrm{hr} . / \mathrm{ml}$. of suspension. The insert shows a plot of $v_{0} / v$ (ratio of uninhibited rate to inhibited rate) against nitrate concentration.

Table 1. Comparative values of the kinetic constants for the oxidation of nitrite by Nitrobacter winogradskyi

$\begin{array}{lcc}\text { Intact } & \begin{array}{c}\text { Cell-free } \\ \text { cells }\end{array} & \begin{array}{l}\text { extract } \\ K_{m}(\mathrm{mM})\end{array} \\ K_{i}(\mu \mathrm{M}) & 1 \cdot 6 & 2 \cdot 2 \\ K_{i}^{\prime \prime}(\mathrm{mM}) & 18 \cdot 5 & 8 \cdot 0 \\ \mathrm{p} K_{b}(\mathrm{M}) & 8 \cdot 3 & 7 \cdot 8\end{array}$

At first, when the oxygen concentration is much greater than $K_{m}$ (oxygen), the reaction proceeds at a constant rate, but when the reverse is true, it follows first-order kinetics. This is shown on Fig. $10 \mathrm{~A}$, where the concentration of oxygen in arbitrary units has been plotted against time. In Fig. 10B the logarithm of the initial amount of oxygen divided by the amount remaining in solution has been plotted against time.

The slope of the semilogarithmic plots gives the first-order rate constant, i.e., according to eqn. (9),

Table 2. Relative rate of oxidation of nitrite by Nitrobacter winogradskyi as a function of the partial pressure of oxygen and the temperature

Different suspensions were used at each temperature. The relative rates of 100 corresponded to oxygen uptakes ( $\mu$ l. of $\mathrm{O}_{2} / \mathrm{hr} . / \mathrm{ml}$. of suspension) of: at $20^{\circ}, 78$; at $23.7^{\circ}$, 45 ; at $29^{\circ}, 143$; at $32^{\circ}, 49$; at $35^{\circ}, 149$.

$\begin{array}{cccc}\text { Temperature } & \begin{array}{c}p_{\mathrm{O}_{2}} \\ (\%)^{2}\end{array} & \begin{array}{c}\text { Concn. of } \\ (\mu \mathrm{M})\end{array} & \begin{array}{c}\text { Relative } \\ \text { rate }\end{array} \\ 20^{\circ} & 21 & 284 & 100 \\ & 7 \cdot 9 & 107 & 95 \cdot 5 \\ & 5 \cdot 25 & 71 & 93 \\ & 2 \cdot 6 & 35 & 79 \cdot 5 \\ 23 \cdot 7 & 21 & 264 & 100 \\ & 7 \cdot 9 & 99 & 94 \\ & 5 \cdot 25 & 66 & 89 \cdot 7 \\ 29 & 2 \cdot 6 & 33 & 80 \cdot 25 \\ & 21 & 240 & 100 \\ & 7 \cdot 9 & 90 & 96 \\ & 5 \cdot 25 & 60 & 84 \cdot 5 \\ 32 & 2 \cdot 6 & 30 & 70 \cdot 25 \\ & 21 & 280 & 100 \\ & 7 \cdot 9 & 86 & 83 \\ & 5 \cdot 25 & 57 & 74 \cdot 75 \\ 35 & 2 \cdot 6 & 28 & 61 \\ & 21 & 218 & 100 \\ & 7 \cdot 9 & 82 & 89 \cdot 5 \\ & 5 \cdot 25 & 55 & 85 \cdot 25 \\ & 2 \cdot 6 & 27 & 58 \cdot 5\end{array}$

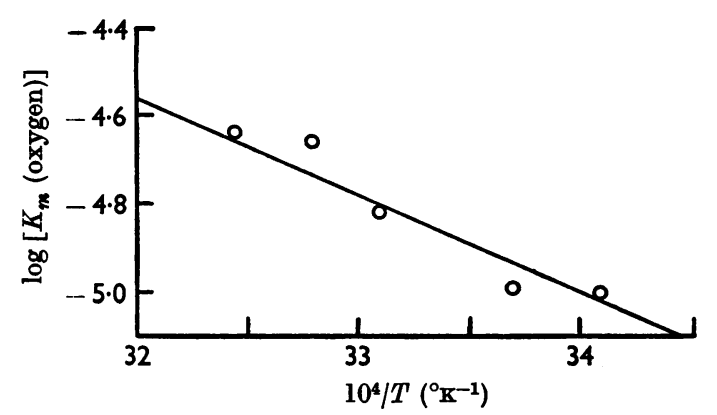

Fig. 9. Logarithm of the Michaelis constant, $K_{m}$ (oxygen), plotted against the reciprocal of the absolute temperature, for the oxidation of nitrite by intact Nitrobacter winogradskyi cells at $\mathrm{pH} \mathbf{7 \cdot 6}$. The substrate concentration was $16 \mathrm{~mm}$. 


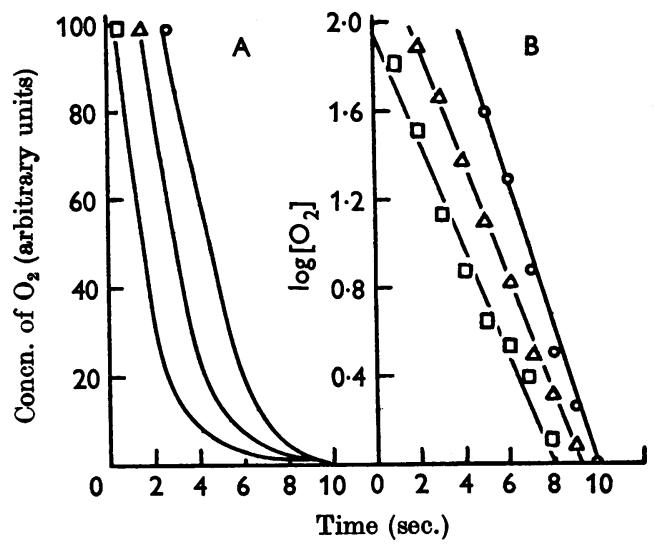

Fig. 10. A. Oxygen uptake plotted as a function of time from the equilibrium oxygen concentration as measured by polarographic current to a negligible small value. A cell suspension of Nitrobacter winogradskyi was incubated at $20^{\circ}(O), 25^{\circ}(\triangle)$ or $30^{\circ}(\square)$ at $\mathrm{pH} 7 \cdot 6$; the substrate concentration was $16 \mathrm{~mm}$. B. The same results plotted according to the first-order rate law.

$V / K_{m}$. It is obvious that the first-order rate constant decreases when the temperature increases, or that the oxidation of nitrite proceeds much more slowly with increasing temperature when the oxygen concentration has fallen below $K_{m}$ (oxygen).

This rather paradoxical result is easily explained from the values of the temperature characteristics of $V$ and $K_{m}$ (oxygen). The temperature characteristic of the overall process, i.e. of $V$, is equal to 9.85 kcal. (Laudelout \& van Tichelen, 1960), and that of $K_{m}$ (oxygen) (as given above) is $12.5 \mathrm{kcal}$. The temperature characteristic of the first-order rate constant may be calculated from the Arrhenius equation:

$$
\frac{V}{K_{m}}=\frac{A \exp (-\mu R / T)}{A^{\prime} \exp \left(-\mu^{\prime} / R T\right)}
$$

where $A$ and $A^{\prime}$ are two constants independent of temperature, and $\mu$ and $\mu^{\prime}$ are the temperature characteristics of $V$ and $K_{m}$ respectively. The temperature characteristic of the first-order rate constant is thus $\left(\mu-\mu^{\prime}\right)$, and since $\mu^{\prime}$ is greater than $\mu$ the reaction must decrease with increasing temperature. The experimentally determined value of the temperature characteristic of $V / K_{m}$ provides an independent determination of $\mu^{\prime}$ : since the Arrhenius plot of the first-order rate constant allows the calculation of an activation energy of -5.5 kcal., it follows that:

$$
\mu^{\prime}=\mu+5 \cdot 5=9 \cdot 85+5 \cdot 5 \cong 15 \mathrm{kcal} \text {. }
$$

We have found by a more direct method the value of $12.5 \mathrm{kcal}$. (Fig. 9). The agreement is fairly satisfactory.

\section{DISCUSSION}

The first conclusions which may been drawn from the data presented in this paper concern the explanation of the difficulties which have been encountered in trying to grow these organisms. If one considers that on the one hand nitrite will always be hydrolysed since nitrous acid is a weak acid, and that on the other hand the latter is a very toxic product as shown by its $K_{i}$ being of the order of magnitude of $10 \mu \mathrm{M}$, it is to be expected that satisfactory growth will only be obtained at low nitrite concentrations. But the yield for the conversion of chemical energy of oxidation into synthesis of cell material is fairly low (about 1 mole of organic carbon synthesized for 90 moles of substrate oxidized with the strain used here). Further, the mean generation time is uncommonly large: $10-15 \mathrm{hr}$. It is easily concluded from these facts that static or continuous cultures could not provide a satisfactory method for growing Nitrobacter cells.

The data on the inhibition by nitrate of the respiration do not explain the inhibition of growth which is observed at nitrate concentrations above $100 \mathrm{~mm}$ (Lees \& Simpson, 1957), since the $K_{i}$ for nitrate is fairly high.

It would be tempting to allude here to permeability effects, but it seems doubtful whether nitrite has to be absorbed by the cell before oxidation takes place. The similarity between the $K_{m}$ values for nitrite for intact cells and cell-free extracts seems to point to an oxidizing system located in the outer cell membrane. Unpublished evidence from electron-microscopic observations of fractionated cell-free extracts seems to lead to the same conclusion.

A similar conclusion might be drawn from the $\mathrm{p} K_{b}$ values of the dissociation constants of the active site in intact cells and cell-free extracts. It is not unreasonable to admit that the basic dissociation constant is somewhat lowered (by about $0.5 \mathrm{pK}$ unit) when the active site is embedded in an organized structure in the cell wall.

\section{SUMMARY}

1. The inhibitory action of nitrite on its own oxidation by a cell suspension or a cell-free extract of Nitrobacter winogradskyi is explained by inhibition by undissociated nitrous acid.

2. The oxidation of nitrite is restricted to a rather narrow $\mathrm{pH}$ range, limited on the acid side by the inhibitory action of nitrous acid and on the alkaline side by the dissociation of an active site of the enzyme system.

3. Nitrate inhibits non-competitively the oxidation of nitrite. 
4. The relationship between the rate of oxidation and the partial pressure of dissolved oxygen has been studied at several temperatures.

5. A discussion of the effect of temperature on the parameters of the rate equations for the oxidation of nitrite is presented.

This work represents part of an investigation supported by the Institut pour l'Encouragement de la Recherche Scientifique dans l'Industrie et l'Agriculture.

\section{REFERENCES}

Aleem, M. I. H. \& Alexander, M. (1958). J. Bact. 76, 510. Butt, W. D. \& Lees, H. (1960). Biochem. J. 76, 425.
Dixon, M. \& Webb, E. C. (1958). Enzymes, p. 126. London: Longman, Green and Co.

Eddy, B. P. (1958). Leeuwenhoek ned. Tijdschr. 24, 81. Goldberg, S. S. \& Gainey, P. L. (1955). Soil Sci. 80, 43.

Hattori, T. \& Furusaka, C. (1960). J. Biochem., Tokyo, 48, 831.

Laudelout, H. \& van Tichelen, L. (1960). J. Bact. 79, 39.

Lees, H. (1958). Nature, Lond., 182, 732.

Lees, H. \& Simpson, J. R. (1957). Biochem. J. 65, 297.

Meyerhof, O. (1916). Pflü. Arch. ges. Physiol. 164, 353.

Shin, M. B. (1941). Industr. Engng Chem. (Anal.), 13, 33.

Silver, W. S. (1960). Trans. 7th int. Congr. Soil Science, Madison, Wis., vol. 2, p. 592.

Zavarzin, G. A. (1958). Mikrobiologiya, 27, 401.

Biochem. J. (1962) 85, 447

\title{
5-Hydroxytryptophol: a Metabolite of 5-Hydroxytryptamine in Rats
}

\author{
BY S. KVEDER, SONJA ISKRIĆ AND DINA KEGLEVIĆ \\ Tracer Laboratory, Institute Rudjer Boskovic, Zagreb, Yugoslavia
}

(Received 25 May 1962)

McIsaac \& Page (1959) and Weissbach, Lovenberg, Redfield \& Udenfriend (1961) found $1^{\prime}-N$ acetyl-5-hydroxytryptamine as a metabolite of 5hydroxytryptamine in rats. Keglevic et al. (1959) found after administration of labelled 5-hydroxytryptamine several radioactive compounds in rat urine, but none of them corresponded to $1^{\prime}-N$ acetyl-5-hydroxytryptamine. Therefore it was thought that this compound, if formed, might be further metabolized or conjugated. On the other hand, Axelrod, Kopin \& Mann (1959), Goldstein, Friedhoff, Pomerantz \& Simmons (1960) and Smith \& Wortis (1960) reported that in the metabolism of some amines intermediate alcohols could be formed. This possibility has been examined for 5-hydroxytryptamine and it will be shown that one of its major metabolites ('metabolite C' of Keglević et al. 1959) is a glucuronide of 5-hydroxy3-( $\beta$-hydroxyethyl)indole (5-hydroxytryptophol).

\section{EXPERIMENTAL}

Materials. 5-Hydroxy[ $\left[1^{\prime}-{ }^{14} \mathrm{C}\right]$ tryptamine as the creatinine sulphate complex $(2 \cdot 26 \mu \mathrm{c} / \mathrm{mg}$.) was prepared as described by Keglević-Brovet, Kveder \& Iskrić (1957). Synthesis of the $N$-acetyl derivative was carried out according to Desaty, Hadžija, Iskrić, Keglević \& Kveder (1962). Bacterial $\beta$-glucuronidase was purchased from Sigma Chemical Co., St Louis, Mo., U.S.A.

5-Hydroxytryptophol. This was prepared as described by Elderfield \& Fischer (1958) for 6-methoxytryptophol. Oxalyl chloride $(2.0 \mathrm{~g}$.) in dry ether $(10 \mathrm{ml}$.) was added dropwise with stirring to a solution of $1.95 \mathrm{~g}$. of 5-benzyloxyindole in dry ether (10 ml.). 5-Benzyloxyindol-3-yloxalyl chloridewas filtered off, washed with ether and added in small portions to a stirred suspension of $\mathrm{LiAlH}_{4}(4 \mathrm{~g}$.$) in$ dry tetrahydrofuran $(40 \mathrm{ml}$.). The mixture was refluxed for $1 \mathrm{hr}$. with stirring and kept at room temperature for an additional $3 \mathrm{hr}$. The complex and the excess of hydride were decomposed with water, and the solution was filtered and evaporated in vacuo, leaving $2 \cdot 15 \mathrm{~g}$. of semicrystalline mass. Three recrystallizations from benzene gave $1.53 \mathrm{~g}$. $(66 \%)$ of 5-benzyloxytryptophol, m.p. 93-95 ${ }^{\circ}$ (Found: C, $76 \cdot 2 ; \mathrm{H}, 6 \cdot 4 ; \mathrm{N}, 5 \cdot 3$. $\mathrm{C}_{17} \mathrm{H}_{17} \mathrm{NO}_{2}$ requires $\mathrm{C}, 76 \cdot 4 ; \mathrm{H}, 6 \cdot 4$; $\mathrm{N}, \mathbf{5 \cdot 2} \%$ ).

The above-mentioned product (534 mg.), dissolved in methanol (25 ml.), was treated at s.t.p. with $10 \% \mathrm{Pd}-$ $\mathrm{BaSO}_{4}(500 \mathrm{mg}$.). After $2 \mathrm{hr}$. the reduction was complete and the catalyst was removed by centrifuging. The solvent was evaporated in vacuo, the residue dissolved in ethyl acetate $(2 \mathrm{ml}$.) and fractionally precipitated with hexane. 5-Hydroxytryptophol was obtained as white prisms (200 mg., 56.5\%), m.p. 102-105 . After one recrystallization from ethyl acetate, m.p. was 105-107 (Found: C, 67.9 ; $\mathrm{H}, 6.5 ; \mathrm{N}, 8.2$. $\mathrm{C}_{10} \mathrm{H}_{11} \mathrm{NO}_{2}$ requires $\mathrm{C}, 67 \cdot 8 ; \mathrm{H}, 6.3$; $\mathrm{N}, 7.9 \%$ ). The compound was stable and showed no tendency to decompose as indicated by Koo, Avakian \& Martin (1959).

Animals. Adult male albino rats from our Institute stock (aged 3-4 months) maintained on a standard diet were used throughout. Injections were applied intraperitoneally, the dose of 5-hydroxy[ $\left[1^{\prime}-14 \mathrm{C}\right]$ tryptamine creatinine sulphate being $2.9 \mathrm{mg} . / 100 \mathrm{~g}$. body wt. The animals were placed in the funnel type of metabolism cage, and were allowed water but no food.

Treatment of urine. Urine $(24 \mathrm{hr}$. sample) was filtered through a glass-wool plug and treated with deactivated 